Sains Malaysiana 50(10)(2021): 3045-3057

http://doi.org/10.17576/jsm-2021-5010-17

\title{
Transgenerational Evaluation of Elateriospermum tapos Extracts on the Male Offspring of Obesity-Induced Sprague Dawley Rats
}

(Penilaian Transgenerasi Ekstrak Elateriospermum tapos pada Zuriat Jantan Tikus Sprague Dawley Teraruh Keobesan)

Santhra Segaran Balan, Azrina Zainal Abidin, Kokila Vani Perumal, Nurul Husna Shafie,

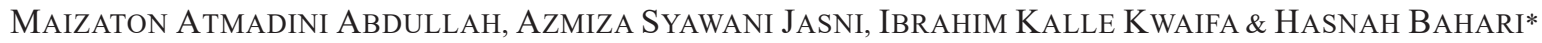

\section{ABSTRACT}

Obesity has been considered as a great public health concern, that has spread in both economic and poor resources countries. This study aimed to investigate the effect of Elateriospermum tapos supplementation on the male offspring of female obesity-induced Sprague Dawley (SD) rats at weaning and adult age. A total of thirty (30) female and fifteen (15) male Sprague Dawley rats $(N=45)$ were purchased for this study. Of the 30 female rats, six $(n=6)$ were randomly selected as the control group (CG) and fed separately with male on standard chow diet, while the remaining rats $(n=24)$ were fed on a high-fat diet for 5 weeks. The obese group were further randomly divided into 4 groups, positive control group (PG), orlistat treatment (DG) at $200 \mathrm{mg} / \mathrm{kg}$, treatment 1 (TX1, $200 \mathrm{mg} / \mathrm{kg}$ E. tapos seed) and treatment 2 (TX2, 200 $\mathrm{mg} / \mathrm{kg}$ E. tapos shell) for 6 weeks. One male pup from each dam was culled at weaning (postnatal day 21 (PND21)) and adulthood (12 weeks). The liver, kidney, retroperitoneal white adipose tissue (RpWAT) and brown adipose tissue (BAT) were collected for histopathological study. Serum lipid profiles, liver enzyme activities and creatinine were measured. The bodyweight of male offspring from treatment 1 (MTX1) and 2 (MTX2) was significantly lower $(P<0.05)$ compare to MNG group. The RpWAT weight in MTX1 and MTX2 for adult offspring also were significantly lower $(P<0.05)$ compared to MPG. The histopathological examination of liver in MCG, MDG, MTX1, and MTX2 showed normal hepatocytes while the MPG group showed the presence of ballooning cell and hypertrophy of adipocytes was also observed in MPG group compared to another group's rat. The E. tapos extracts from the shell have greater therapeutic potential on maternal obesity in short and long term treatment.

Keywords: Elateriospermum tapos; high-fat diet; maternal obesity; total cholesterol

\section{ABSTRAK}

Keobesan merupakan masalah kesihatan yang besar dan telah merebak di seluruh dunia termasuk negara maju dan miskin. Tujuan kajian ini dijalankan adalah untuk mengkaji kesan suplemen Elateriospermum tapos terhadap keobesan anak tikus jantan Sprague Dawley (SD) yang berusia 21 hari dan 12 minggu. Sebanyak tiga puluh (30) tikus betina dan lima belas (15) tikus jantan Sprague Dawley $(N=45)$ digunakan dalam kajian ini. Daripada 30 tikus betina, enam $(n=$ 6) dipilih secara rawak sebagai kumpulan kawalan (CG) dan diberi makanan tikus secara berasingan, manakala tikus yang lain $(n=24)$ diberi makanan yang mengandungi tinggi lemak selama 5 minggu secara berterusan. Kumpulan tikus obes ini, seterusnya dibahagikan secara rawak kepada 4 kumpulan, kumpulan kawalan positif (PG), rawatan orlistat (DG) pada $200 \mathrm{mg} / \mathrm{kg}$, rawatan 1 (TX1, $200 \mathrm{mg} / \mathrm{kg}$ biji E. tapos) dan rawatan 2 (TX2, $200 \mathrm{mg} / \mathrm{kg} \mathrm{kulit}$ biji E. tapos) selama 6 minggu. Seekor tikus jantan dikorbankan pada hari ke 21 (PND21) dan juga pada usia 12 minggu (dewasa). Hati, ginjal, tisu adipos putih (RpWAT) dan tisu adipos coklat (BAT) dikumpulkan untuk kajian histopatologi. Profil lipid serum, enzim hati dan kreatinin diukur. Berat badan tikus jantan daripada kumpulan rawatan 1 (MTX1) dan 2 (MTX2) didapati jauh lebih rendah $(P<0.05)$ berbanding dengan kumpulan MNG. Berat RpWAT daripada kumpulan MTX1 dan MTX2 adalah jauh lebih rendah $(P<0.05)$ berbanding dengan kumpulan MPG. Pemeriksaan histopatologi hati di bawah mikroskop bagi MCG, MDG, MTX1 dan MTX2 menunjukkan sel hepatosit yang normal manakala kumpulan MPG mendedahkan adanya sel belon dan kehadiran hipertrofi adiposit juga diperhatikan pada MPG berbanding dengan tikus daripada kumpulan yang lain. Ekstrak E. tapos daripada cengkerang mempunyai potensi terapeutik yang lebih besar terhadap keobesan ibu dalam rawatan jangka masa pendek dan jangka masa panjang.

Kata kunci: Diet tinggi lemak; Elateriospermum tapos; ibu yang obes; total kolesterol 


\section{INTRODUCTION}

Overweight or obesity is a major global problem. In 2014, $61.7 \%$ of young adults and $31.2 \%$ of children in the UK were overweight or categorized as obese (Bucksch et al. 2017). Numerous studies have shown that children borne from obese mothers are more likely to have increased body weight due to higher levels of lipid and are more prone to higher insulin resistance (Ribaroff et al. 2017). Gender preferences in the animal study have indicated that sex hormone serves a significant function in lipid metabolism. This was reported to be associated with the declining oestrogen levels during premenopausal life. Oestrogen was reported to interfere and suppress the activities of leptin; a hormone that enhances lipid uptake in the system. Based on this, the male rat was identified to be a good candidate in research related to lipid metabolisms (Rodriguez-Leyva et al. 2011). Modifications of food intake during breastfeeding or maternity will lead to changes in the metabolic phenotype, the cardiovascular functions, behaviour and the ability of learning and motivation to the offspring (Mery et al. 2014). An extensive study has shown that this disorder might be due to an increase in adiposity and other components of the metabolic syndrome in offspring (Armitage et al. 2005). Offspring on cafeteria diet during gestation and lactation would have increased adiposity at weaning which could be identified by the increased fat pad and intramuscular fat deposition. The previous developmental over-nutrition hypothesis suggested that maternal obesity during the gestational period in humans might predispose the future offspring to energy imbalance and increased adiposity in adulthood, leading to cardiovascular diseases and its related complications (Catalano 2003; Catalano et al. 2003a, 2003b; Oken \& Gillman 2003). This explains the association between excessive weight increased during pregnancy and the BMI of the adolescent child (Harvey et al. 2007; Kirk et al. 2009; Lawlor et al. 2007; Oken 2008). Several studies on experimental animals reported that nutritional modification during pregnancy and lactation might lead to permanent alteration of the food intake because of developmental plasticity in the hypothalamus (FerezouViala et al. 2007). Changes in the organ weight, due to an increase in body weight, might indicate the sensitivity towards organs toxicity (McCurdy et al. 2009).

The used of conventional medicine for the treatment of obesity in the current world has become a challenge, because of unpredictable side effects (Perumal et al. 2019). Alternative medicine, specifically natural products have become useful in reducing body weight, with fewer or no side effects among obese people (Awang et al. 2003). E. tapos is a monoecious tropical canopy species available in Southeast Asian, including Peninsular Thailand, Peninsular Malaysia, Sumatra, Java as well as Borneo tropical rain forest. The previous study has indicated that almost every part of this tree can be utilized (Yong \& Salimon 2006). A previous study on E. tapos seed and shell demonstrated that E. tapos shell has a higher level of total phenolic content and flavonoids compared to E. tapos seed (Nor-Liyana et al. 2019). Apart from this compound, E. tapos also have alpha-amylase, alphaglucosidase and pancreatic enzymes which help to limit the absorption of lipids and carbohydrate in the body, subsequently leading to a reduction in body weight (Balan et al. 2019). Other organic compounds present in $E$. tapos that have been shown to have numerous biological activities include alkaloids, tannins, steroids, saponins, iodine, proteins and natural oil, which were believed to have a medicinal function in the treatment of various health conditions (Park 2011; Yong \& Salimon 2006). Therefore, this study was conducted to determine the therapeutic effect of E. tapos extracts on maternal obesity promoted by metabolic changes in rats' male offspring at PND21 and adulthood.

\section{MATERIALS AND METHODS}

\section{Elateriospermum tapos PLANT IDENTIFICATION}

Elateriospermum tapos was collected from Maran, Pahang for identification. The sample was sent to Herbarium Biodiversity Unit (UBD) at UPM and the voucher of the specimen was obtained (UPM SK 3154/17).

\section{Elateriospermum tapos EXTRACTION}

The hot aqueous method was used for the extraction of E. tapos shell and seed compound. Both shell and seed $(50 \mathrm{~g})$ were ground, mixed and dissolved in $500 \mathrm{~mL}$ of distilled water in a different conical flask. The mixture was further dissolved in a water bath at $70{ }^{\circ} \mathrm{C}$ for $24 \mathrm{~h}$ and filtered three times using Whatman paper No 1 and stored in the falcon tube at $-20^{\circ} \mathrm{C}$. The samples were Freezedried, and the powder was obtained (Balan et al. 2019; Perumal et al. 2019).

\section{INDUCTION OF OBESITY}

The high-fat diet was prepared by mixing with $68 \%$ standard rat pellet (Gordon Specialty Stockfeed, Malaysia), 6\% corn oil (Vecorn), 20\% milk powder 
(Dutch Lady), and 6\% ghee (Crispo). The ingredients were blended and mixed before baking in the oven at $60{ }^{\circ} \mathrm{C}$ for $2 \mathrm{~h}$. The HFD was cut into small pieces and stored in the fridge (Balan et al. 2019; Perumal et al. 2019). Selected cafeteria food (CF) such as marble cake (440 kcal/100 g), beef sausage (260 kcal/100 g), and savoury snacks (566 $\mathrm{kcal} / 100 \mathrm{~g}$ ) were also given to induce obesity. The female rats were given HFD with energy value (414 kcal/100 g) made of $43 \%$ carbohydrate, $17 \%$ proteins, and $40 \%$ fats.

\section{ANIMAL EXPERIMENTAL STUDY DESIGN}

All procedure involving animal care was conducted under the approval of the Animal Care and Ethics Committee of the Management and Science University, AE-MSU-073. A total of thirty female $(n=30)$ and fifteen male $(n=15)$, Sprague Dawley rats, weighing between $150 \mathrm{~g}$-200 $\mathrm{g}$ and age 12-13 weeks were used in this research (KRK Seri Enterprise, Selangor, Malaysia). The rats were housed at $20 \pm 2{ }^{\circ} \mathrm{C}$ and maintained on a 12:12 $\mathrm{h}$ light/dark cycle. Upon receiving, the rats were acclimatized for one week and allowed for food and water ad libitum. The male rats were kept separate from the female. The female rats were divided randomly into two groups. The control group (CG), consisting of 6 rats and the remaining twenty-four rats as a high-fat diet (HFD) group. The CG group and the male rats were fed with standard chow diet, composed of $306.2 \mathrm{kcal} / 100$ $\mathrm{g}$ with $59 \%$ as carbohydrate, $26 \%$ as protein, and $16 \%$ as fat. The HFD groups were given HFD and selected cafeteria food (CF) for five weeks to induce obesity. The body weight and calorie intake of the rats were recorded weekly to monitor the percentage of body weight. After the confirmation of obesity, by comparing the lipid profile results of HFD group with the CG group, the HFD group rats were randomly divided into 4 different groups (each group with $n=6$ rats). The groups included the positive control group (PG), drug treatment (DG) with Orlistat administration group $(200 \mathrm{mg} / \mathrm{kg})$, TX1 with E. tapos seed at $200 \mathrm{mg} / \mathrm{kg}$ and TX2 with E. tapos shell at $200 \mathrm{mg} / \mathrm{kg}$ (Balan et al. 2019; Perumal et al. 2019). After six weeks, the rats were mated, at two females to one male rat, placed in a cage for $24 \mathrm{~h}$. The vagina smear conducted and the mating was confirmed, all the pregnant female rats were retained, and the gestation was designated as day 0 and immediately after birth, the treatment was stopped. Within two days of birth, six (6) male pups $n=30$ ) were randomly selected from each group and the female was taken to the animal house for future use. Except for the positive controls, all pups consumed standard chow diet from weaning until adulthood. Pups were weighed every two days until weaning postnatal day (PND21) and continued for week 12 using an electronic scale.

\section{TISSUE COLLECTION}

Dams, offspring at PND21 and adult rats were anaesthetized by ketamine injection and sacrificed. Blood was rapidly collected by cardiac puncture and culled by cervical dislocation. Organs, including liver, retroperitoneal white adipose tissue (RpWAT), brown adipose tissue (BAT), kidney and heart were collected, washed with normal saline and weighed. Tissue was immersed in $10 \%$ neutral buffered formalin (NBF) for histological analysis.

\section{SERUM BIOCHEMISTRY}

About $5 \mathrm{~mL}$ of blood volume was collected through cardiac puncture and poured into plain vacutainer tubes and centrifuged at 2,500 RPM for $15 \mathrm{~min}$ to obtain serum. Serum creatinine, ALT, AST, total cholesterol (TC), triglycerides (TG), high-density lipoprotein (HDL) and low-density lipoprotein (LDL) were measured using Alere Cholestech LDX ${ }^{\circledR}$ Analyzer (3230 Bethany Lane Suite 8, Ellicott City, MD 21042).

\section{HISTOLOGICAL ANALYSIS}

The fixed tissues were processed in different concentrations of alcohol and xylene before embedded in paraffin wax. The tissues were sectioned to obtain a thin layer of about $4 \mu \mathrm{m}-7 \mu \mathrm{m}$ thickness followed by fixing using a clean slide. The slides were de-waxed and stained with Hematoxylin \& Eosin (H\&E) stain, dried at room temperature and mounted. The tissues were examined by light microscope and histological changes identified under different objectives (Sanaa et al. 2014).

\section{HISTOPATHOLOGICAL ASSESSMENT OF TOXICITY}

The lesion scoring of the liver and kidney was conducted according to Nassir et al. (2015) and Ramli (2005) methods, respectively. Liver steatosis is scored based on the percentage of fat surrounding the hepatocytes (Dyson et al. 2014; Nassir et al. 2015) and examined by the two independent pathologists. 


\begin{tabular}{|c|c|c|}
\hline Tissue & Grade/Score & Interpretation \\
\hline \multirow[t]{4}{*}{ Liver } & $0(<5 \%)$ & Normal \\
\hline & $1(5-33 \%)$ & Mild \\
\hline & $2(34-66 \%)$ & Moderate \\
\hline & $3(>66 \%)$ & Severe (Dyson et al. 2014; Nassir et al. 2015) \\
\hline \multirow[t]{4}{*}{ Kidney } & 0 & Normal \\
\hline & 1 & $\begin{array}{l}\text { There was slight hyperemia. The epithelium was slightly detached from the } \\
\text { basement membrane of bowman's capsule and the glomerulus was slightly } \\
\text { shrunken }\end{array}$ \\
\hline & 2 & $\begin{array}{l}\text { Moderate hyperemia and the epithelium were moderately detached from the } \\
\text { basement membrane of the bowman's capsule. Glomerulus was moderately } \\
\text { shrunken with damaged basement membrane }\end{array}$ \\
\hline & 3 & $\begin{array}{l}\text { There was hyperemia and the epithelium was highly detached from the basement } \\
\text { membrane of the bowman's capsule } \\
\text { Glomerulus was severely shrunken with damaged basement (Ramli 2005) }\end{array}$ \\
\hline
\end{tabular}

\section{STATISTICAL ANALYSES}

The SPSS version 25.0 was used to analyses the statistical data and results were expressed as mean \pm SEM. A normality test was done for all the data. Bodyweight, organ weight, calorie intake, and plasma biochemistry data of dams after treatment was analyzed by oneway ANOVA, followed by post hoc LSD. In all analyses, a probability of $p<0.05$ was considered statistically significant.

\section{RESULTS AND DISCUSSION}

Changes in the lifestyle have grossly promoted the incidence of obesity globally (Kwaifa et al. 2020). The previous study has investigated that people eating behaviour are associated with several metabolic disorders and might give a significant impact on the progress of obesity in both human and animal. This situation can be observed in the high number of obese people and pregnant women (Calton et al. 2014). Overconsumption of caloric intake during pregnancy changes a short- and long-term maternal wellbeing that leads to health risks, including excessive weight gain, diabetes, high blood pressure as well as cardiovascular disease. Obesity during pregnancy and gestational period result in weight gain, changes in the intrauterine condition, and subsequently increased in the offspring's body weight (Fu et al. 2016). In most of the animal studies on obesity, the results have shown a significant increase in body weight which correlates with an increase in caloric consumption (Kumeshini et al. 2016; Zhao et al. 2005).

\section{THE GROWTH OF MALE PUP'S BODY WEIGHT FROM DAY 1 TO 21 AND WEEKS 4 TO 12}

Bodyweight of HFD mothers and male pups from the MCG was measured from day 1 to 21 and from week 4 to 12. Male pups from the MPG group showed significantly $(p<0.05)$ increased in weight gain compared to pups MCG (Figure 1). Male pups from the MDG, MTX1 and MTX2 showed a significant reduction $(\mathrm{p}<0.05)$ in body weight compared to MPG group. Except for the MPG, the bodyweight of all the other groups were relatively similar to MCG pups. The bodyweight of MPG showed significantly $(p<0.05)$ increased from week 4 to 12 compared to the MCG group, while the body weight from the adult treatment groups was observed to be the same with the pups. Adult rats from MDG, MTX1, MTX2, and pups from the MCG group, have lower body weight compared to MPG group rats (Figure 1).

In this present study, the results obtained showed that offspring at PDN12 from MPG showed a significant increase in body weight and a similar result was obtained among adult offspring at week 12 . However, $E$. tapos treated groups (MTX1 \& 2) showed a significant decrease in body weight of offspring at PDN 21 as well as adult week 12 . The previous study also demonstrated that obesity is mainly caused by HFD with the increased 
caloric intake (Noor et al. 2015). It believes that fat has high dense energy and nutrient compared to carbohydrates and proteins, this might be the reason that leads to both increases in body and organ weights. Diet rich in fat and cafeteria foods induced obesity not only in humans but also in animal models (Akadiri \& Kabirou 2011). Apart from that, the physiological signal also contributed to the uptake of food among animal and human. Different types of food will cause different physiological responses to both animal and human (Wardani et al. 2019).

\section{Body weight (day 1- 21)}

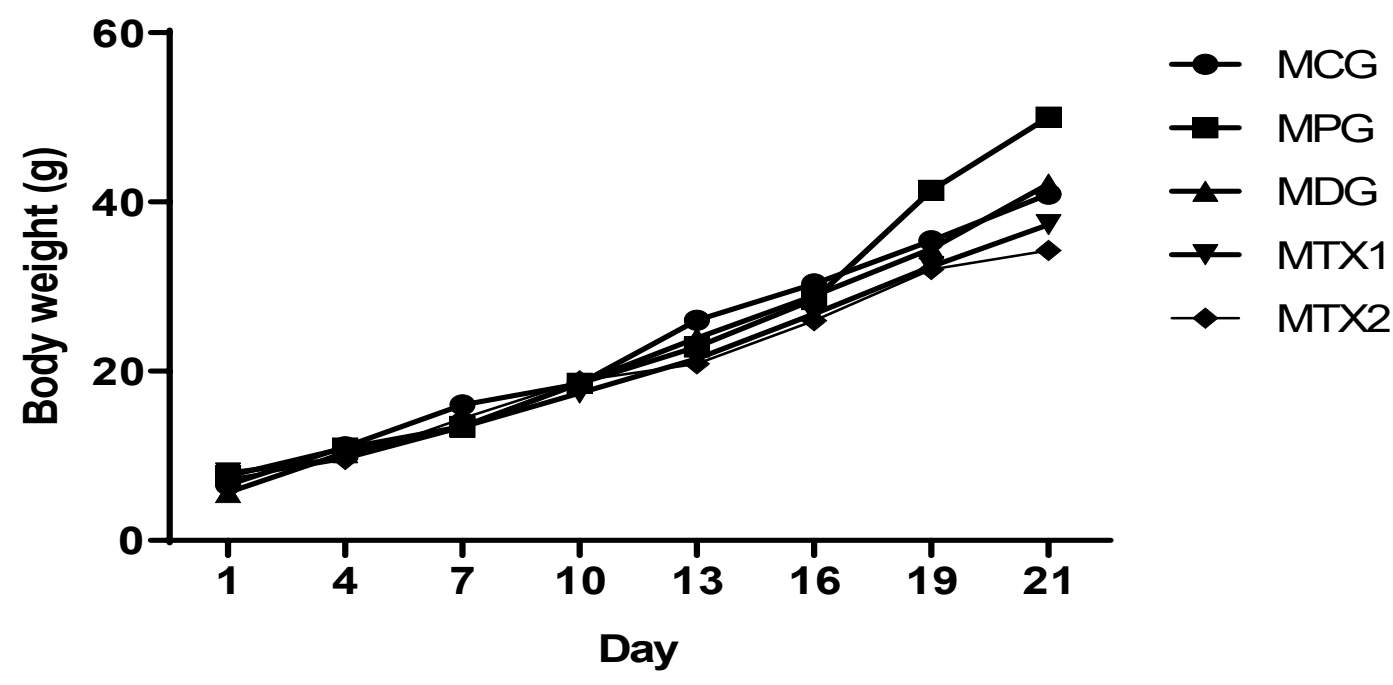

Body weight (week 4-12)

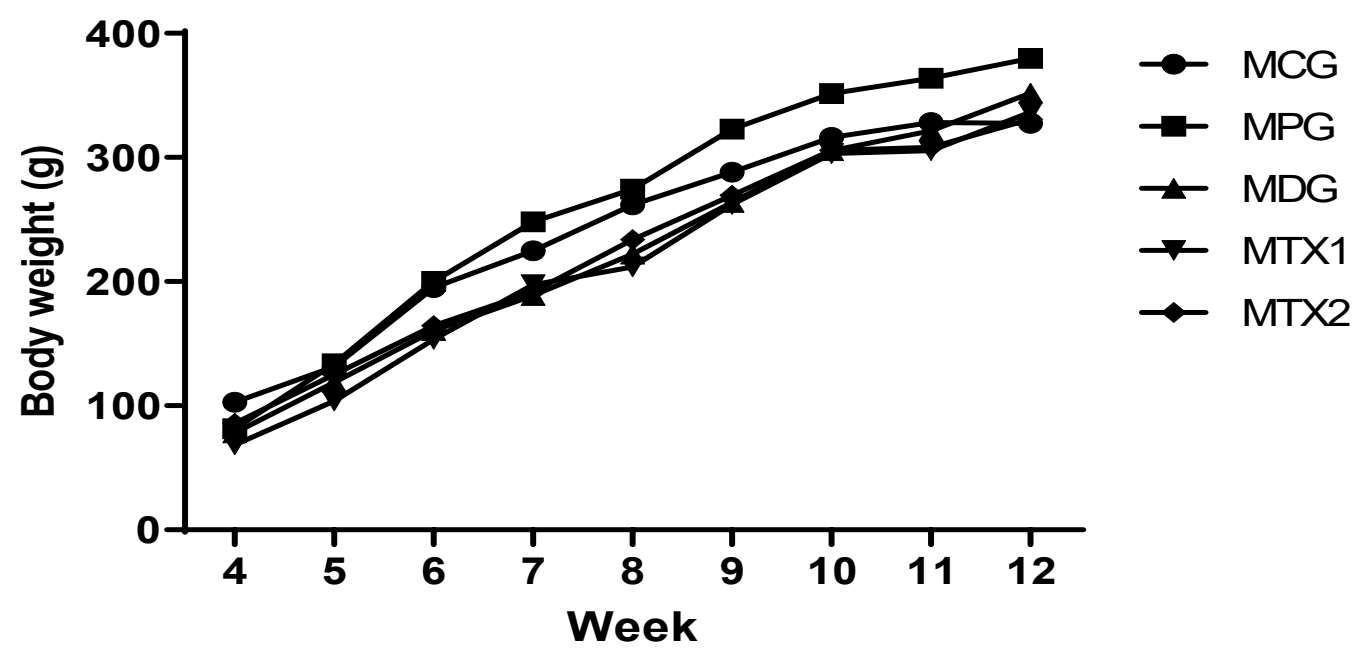

M; male offspring, MCG; male control group, MPG; male positive control, MDG; male drug treatment group, MTX1; dams treated with seed group, MTX2; dams treated with shell group

FIGURE 1. Impacts of E. tapos on body weight of male pups from day 1 until week 12 
IMPACTS OF E. tapos ON ORGAN WEIGHTS OF MALE PUPS AT PND1 AND WEEK 12

Brown adipose tissue (BAT) weight among male pups at PND21 indicated that the MPG group showed significantly $(p<0.05) 60.5 \%$ increase compared to the MCG group. However, BAT weight was observed to be slightly decreased in MDG, MTX1, and MTX2 (28.2\%, $18.18 \%$ \& $38.46 \%$ ) compared to MPG group pups. Hence, the adult pups at week 12 showed no significant changes among all the groups. This may be due to the higher levels of BAT present in new-born compared to adult rats. RpWAT in adult male (Week 12) showed significant changes in all groups compared to pups PND21. In particular, the RpWAT in MPG adult pups at week 12 showed a significant increase $(\mathrm{p}<0.05)$ compared to the MCG group. Also, the MDG, MTX1, and MTX2 in adult pups showed decreased weight compared to the MPG. The RpWAT among male pups at PND21 were shown to have no significant changes in all groups. The total adiposity in MCG groups showed significant changes $(\mathrm{p}<0.05)$ among the rats in week 12, but at PND21 no significant changes were recorded. The liver weight in the MPG group was significantly heavier $(\mathrm{p}<0.05)$ in PND21 and week 12 compared to the MCG group. Moreover, the liver weight of MPG, MDG, MTX1, and MTX2 at PND21 showed significant changes $(\mathrm{p}<0.05)$ compared with the MCG group. The kidney and heart weight at PND21 and week 12 recorded no significant changes among treatment groups compared to MPG group (Table 1). Previous reports concluded that maternal obesity promoted a significant increase in post-weaning adiposity; even though the offspring consumed low-fat chow. In this study, male offspring at PDN21 and adult at week 12 from the MPG showed a significant increase in both body and organ weight, such as liver, kidney, as well as adipose tissue, compared to all other groups. However, the male offspring at PDN21 with E. tapos extract supplement (MTX1 \& 2) showed a significant decreased in body and organ weight.

TABLE 1. Impacts of E. tapos on organ weight of male pups at PND21 and week 12

\begin{tabular}{|c|c|c|c|c|c|c|}
\hline Male organ weight (g) & Age & $\begin{array}{l}\text { MCG } \\
(n=6)\end{array}$ & $\begin{array}{l}\text { MPG } \\
(n=6)\end{array}$ & $\begin{array}{l}\text { MDG } \\
(n=6)\end{array}$ & $\begin{array}{l}\text { MTX1 } \\
(n=6)\end{array}$ & $\begin{array}{l}\text { MTX2 } \\
(\mathrm{n}=6)\end{array}$ \\
\hline \multirow[t]{4}{*}{ RpWAT } & PND 21 & 0.45 & 0.91 & 0.59 & 0.76 & 0.49 \\
\hline & & \pm 0.16 & \pm 0.19 & \pm 0.28 & \pm 0.30 & \pm 0.21 \\
\hline & Week 12 & 2.90 & 7.16 & 5.64 & 9.63 & 6.49 \\
\hline & & $\pm 7.45^{\mathrm{a}}$ & $\pm 1.34^{\mathrm{b}}$ & \pm 0.74 & $\pm 2.05^{\mathrm{b}, \mathrm{c}}$ & $\pm 1.10^{\mathrm{b}}$ \\
\hline \multirow[t]{4}{*}{ BAT } & PND 21 & 0.15 & 0.38 & 0.28 & 0.33 & 0.24 \\
\hline & & $\pm 0.04^{\mathrm{a}}$ & $\pm 0.08^{\mathrm{b}}$ & \pm 0.04 & $\pm 0.05^{\mathrm{a}}$ & $\pm 0.02^{\mathrm{b}}$ \\
\hline & Week 12 & 0.68 & 0.87 & 0.76 & 0.79 & 0.58 \\
\hline & & \pm 0.09 & \pm 0.12 & \pm 0.11 & \pm 0.12 & \pm 0.08 \\
\hline \multirow[t]{4}{*}{ Total adipose tissue } & PND 21 & 0.54 & 1.53 & 1.37 & 1.13 & 1.10 \\
\hline & & \pm 0.13 & \pm 0.35 & \pm 0.62 & \pm 0.30 & \pm 0.11 \\
\hline & Week 12 & 5.63 & 13.07 & 11.42 & 16.23 & 14.04 \\
\hline & & $\pm 1.13^{\mathrm{a}, \mathrm{c}}$ & $\pm 2.18^{\mathrm{b}}$ & $\pm 1.25^{\mathrm{b}}$ & $\pm 2.43^{\mathrm{b}}$ & $\pm 2.10^{\mathrm{b}}$ \\
\hline \multirow[t]{4}{*}{ Liver } & PND 21 & 1.67 & 3.09 & 1.94 & 1.91 & 1.76 \\
\hline & & $\pm 0.31^{\mathrm{a}}$ & $\pm 0.35^{\mathrm{b}}$ & $\pm 0.24^{\mathrm{b}}$ & $\pm 0.13^{\mathrm{b}}$ & $\pm 0.11^{\mathrm{b}}$ \\
\hline & Week 12 & 10.10 & $15 . .56$ & 14.46 & 12.67 & 11.71 \\
\hline & & $\pm 1.36^{\mathrm{a}, \mathrm{c}}$ & $\pm 0.83^{\mathrm{b}}$ & $\pm 0.58^{\mathrm{b}}$ & $\pm 0.45^{\mathrm{b}}$ & $\pm 1.06^{\mathrm{a}, \mathrm{c}}$ \\
\hline \multirow[t]{4}{*}{ Kidney } & PND 21 & 0.53 & 0.92 & 0.73 & 0.52 & 0.50 \\
\hline & & \pm 0.07 & \pm 0.19 & \pm 0.35 & \pm 0.02 & \pm 0.05 \\
\hline & Week 12 & 2.25 & 2.90 & 2.70 & 2.61 & 2.40 \\
\hline & & \pm 0.34 & \pm 0.15 & \pm 0.19 & \pm 0.40 & \pm 0.23 \\
\hline \multirow[t]{4}{*}{ Heart } & PND 21 & 0.25 & 0.50 & 0.40 & 0.29 & 0.28 \\
\hline & & \pm 0.05 & \pm 0.14 & \pm 0.17 & \pm 0.02 & \pm 0.03 \\
\hline & Week 12 & 1.09 & 1.59 & 1.33 & 1.30 & 1.29 \\
\hline & & $\pm 0.07^{\mathrm{c}}$ & \pm 0.09 & $\pm 0.05^{\mathrm{b}}$ & $\pm 0.11^{\mathrm{b}}$ & \pm 0.04 \\
\hline
\end{tabular}

RpWAT; retroperitoneal white adipose tissue, BAT; brown adipose tissue, Total adipose tissue represents the sum of RP, Visceral, and Uterine WAT mass, M; male offspring, MCG; male control group, MPG; male positive control, MDG; male drug treatment group, MTX1; treatment 1 group, MTX2; treatment 2 group. Data are expressed as mean \pm SEM and were analyzed by one-way ANOVA, followed by post-hoc LSD. Significant level set at $p<0.05$. ${ }^{a} p<0.05$ versus negative control, ${ }^{b} p$ $<0.05$ versus normal control, ${ }^{c} \mathrm{p}<0.05$ versus positive control 
IMPACTS OF E. tapos ON LIPID PROFILE ANALYSIS IN MALE PUPS AT PND21 AND WEEK 12

The total cholesterol (TC) among pups at PND21 in MPG group showed significant increased $(\mathrm{p}<0.05)$ compared to the MCG group. However, the MTX1 and MTX2 groups showed a slight reduction in TC compared to MPG. Also, pups at week 12 observed slight significant changes among all the groups compared to MPG. The HDL level at PND21 pups of MPG recorded a significant decrease compared to all other treatment groups. Except in MPG, the HDL level among pups at week 12 shows no significant changes in all the groups. The LDL levels, at PND21, indicated no significant changes in all the groups. However, at week 12, the LDL levels recorded significant changes between MCG and MPG groups whereas there were no significant changes recorded among all the treatment groups. The TGs levels at PND21 of MPG showed significant changes compared to all other groups. Additionally, the TGs levels in MPG at week 12 showed significant changes $(p<0.05)$ compared to the MDG group. Likewise, the treatment groups also showed significant changes compared to MPG and MDG groups (Table 2).
In this study, we found that the selective maternal overnutrition and overeating exposure in male offspring at weaning at PND21 and adulthood at week 12 lead to increase in TC and TG levels compared to the offspring from E. tapos extract treated groups. This is associated with increased in RpWAT and liver weight. A previous study conducted by Cardenas-Perez et al. (2018), reported similar results where the obese rats showed an increase in body weight, TC, and TG levels. Unsaturated triglyceride caused up-regulating of LDL receptors compared to saturated triglycerides. Diet with HFD made changes in cellular membrane lipids and this might have a profound effect on receptor-mediated uptake to lipoproteins. The previous study showed that total phenolic content (TPC) and total flavonoids content in shell extract is higher compare to seed extract. DPPH antioxidant and $\beta$-antioxidant activity in shell show higher than the seed of E. tapos (Nor-Liyana et al. 2019). A study has shown that the E. tapos extract-treated groups recorded low TC and TG levels. This may be due to E. tapos flavonoids compound known as 3'4'5' Trimethoxyflavone that play a role in reducing fat deposits by increasing the oxidation of fatty acids and reduced adipogenesis by increase the lipolysis (Cardenas-Perez et al. 2018; Husin et al. 2013).

TABLE 2. Impacts of E. tapos on lipid profile of male pups at PND21 and week 12

\begin{tabular}{|c|c|c|c|c|c|c|}
\hline & Age & $\begin{array}{l}\text { MCG } \\
(n=6)\end{array}$ & $\begin{array}{l}\text { MPG } \\
(n=6)\end{array}$ & $\begin{array}{l}\text { MDG } \\
(n=6)\end{array}$ & $\begin{array}{l}\text { MTX1 } \\
(n=6)\end{array}$ & $\begin{array}{l}\text { MTX2 } \\
(n=6)\end{array}$ \\
\hline \multirow{2}{*}{$\mathrm{TC}$} & \multirow{2}{*}{ PND 21} & 1.83 & 2.58 & 2.37 & 2.10 & 2.23 \\
\hline & & $\pm 0.08^{\mathrm{a}, \mathrm{c}}$ & $\pm 0.19^{\mathrm{b}}$ & $\pm 0.13^{\mathrm{b}}$ & $\pm 0.10^{\mathrm{a}}$ & $\pm 0.15^{\mathrm{b}}$ \\
\hline \multirow{6}{*}{ HDL } & \multirow{2}{*}{ Week 12} & 1.48 & 1.73 & 1.55 & 1.68 & 1.62 \\
\hline & & \pm 0.07 & \pm 0.07 & $\pm 0.11^{\mathrm{b}}$ & \pm 0.15 & \pm 0.13 \\
\hline & \multirow{2}{*}{ PND 21} & 0.47 & 0.40 & 0.62 & 0.62 & 0.55 \\
\hline & & $\pm 0.07^{\mathrm{a}}$ & $\pm 0.07^{\mathrm{b}}$ & \pm 0.04 & \pm 0.08 & \pm 0.06 \\
\hline & \multirow{2}{*}{ Week 12} & 0.33 & 0.28 & 0.38 & 0.45 & 0.40 \\
\hline & & \pm 0.03 & \pm 0.02 & \pm 0.3 & \pm 0.05 & \pm 0.06 \\
\hline \multirow{2}{*}{ LDL } & \multirow{2}{*}{ PND 21} & 1.25 & 1.40 & 1.33 & 1.27 & 1.32 \\
\hline & & \pm 0.25 & \pm 0.27 & \pm 0.22 & \pm 0.13 & \pm 0.18 \\
\hline \multirow{6}{*}{ TG } & \multirow{2}{*}{ Week 12} & 0.62 & 0.98 & 0.73 & 0.61 & 0.72 \\
\hline & & $\pm 0.10^{\mathrm{b}}$ & $\pm 0.07^{\mathrm{a}}$ & \pm 0.02 & $\pm 0.11^{\mathrm{b}}$ & \pm 0.05 \\
\hline & \multirow{2}{*}{ PND 21} & 1.60 & 2.43 & 1.65 & 1.57 & 1.20 \\
\hline & & \pm 0.91 & \pm 0.98 & \pm 0.35 & \pm 0.30 & \pm 0.22 \\
\hline & \multirow{2}{*}{ Week 12} & 0.69 & 2.78 & 1.71 & 1.55 & 1.08 \\
\hline & & $\pm 0.07^{\mathrm{c}}$ & $\pm 0.14^{\mathrm{a}}$ & $\pm 0.72^{\mathrm{a}, \mathrm{b}}$ & $\pm 0.42^{\mathrm{a}, \mathrm{b}}$ & $\pm 0.25^{\mathrm{c}}$ \\
\hline
\end{tabular}

TC; total cholesterol, HDL; high-density lipoprotein, LDL; low-density lipoprotein, TG; triglyceride, M; male offspring, MCG; male control group, MPG; male positive control, MDG; male positive group, MTX1; treatment 1 group, MTX2; treatment 2 group. Data are expressed as mean \pm SEM and were analysed by one-way ANOVA, followed by post-hoc LSD. Significant level set at $\mathrm{p}<0.05$. ${ }^{\mathrm{a}} \mathrm{p}<0.05$ versus positive control, ${ }^{\mathrm{b}} \mathrm{p}<0.05$ versus normal control, ${ }^{\mathrm{c}} \mathrm{p}<0.05$ versus drug treatment 
IMPACTS OF E. tapos ON LIVER AND KIDNEY PROFILE IN MALE PUPS AT PND21 AND WEEK 12

This present study recorded that ALT level was significantly $(p<0.05)$ higher in MPG group compared to all the other groups in pups at PND21 but there were no significant changes recorded at week 12 . There were no significant changes also observed between the treatment groups. The AST levels between other groups and MPG offspring also showed significant differences among pups at PND21 and week 12 but there were no significant changes recorded among the treatment groups.
The creatinine level among pups at PND21 and week 12 indicated no significant changes in all the groups, however, the levels varied among these groups (Table 3 ).

This present study reported an increase in liver enzymes, including ALT and AST among MPG groups compared to the E. tapos extract treated groups (MTXI \& 2). This may be due to the abnormalities in the liver caused by the intake of HFD. The intake of HFD and cafeteria food increased in the fat level that might cause dysfunction in mitochondria and mononuclear inflammation (Institute of Medicine USA 2004).

TABLE 3. Impacts of E. tapos liver and kidney profile in male pups at PND21 and week 12

\begin{tabular}{|c|c|c|c|c|c|c|}
\hline & Age & $\begin{array}{l}\text { MCG } \\
(n=6)\end{array}$ & $\begin{array}{l}\text { MPG } \\
(n=6)\end{array}$ & $\begin{array}{l}\text { MDG } \\
(n=6)\end{array}$ & $\begin{array}{l}\text { MTX1 } \\
(n=6)\end{array}$ & $\begin{array}{l}\text { MTX2 } \\
(n=6)\end{array}$ \\
\hline \multirow[t]{4}{*}{ AST } & PND 21 & 193.50 & 233.67 & 199.33 & 168.00 & 198.40 \\
\hline & & \pm 20.47 & \pm 24.23 & \pm 23.54 & $\pm 9.23^{\mathrm{a}, \mathrm{c}}$ & \pm 23.73 \\
\hline & Week 12 & 177.67 & 188.50 & 134.17 & 174.00 & 184.17 \\
\hline & & \pm 19.66 & \pm 16.38 & \pm 14.29 & \pm 18.71 & \pm 23.74 \\
\hline \multirow[t]{4}{*}{ ALT } & PND 21 & 43.83 & 55.33 & 44.67 & 43.50 & 44.10 \\
\hline & & $\pm 3.20^{\mathrm{a}}$ & $\pm 1.98^{\mathrm{b}}$ & \pm 3.11 & $\pm 3.48^{\mathrm{a}}$ & $\pm 5.13^{\mathrm{a}}$ \\
\hline & Week 12 & 46.50 & 46.77 & 45.00 & 45.00 & 44.87 \\
\hline & & \pm 1.86 & \pm 2.95 & \pm 3.50 & \pm 2.25 & \pm 3.66 \\
\hline \multirow[t]{4}{*}{ Creatinine } & PND 21 & 19.17 & 22.17 & 20.17 & 19.67 & 20.80 \\
\hline & & \pm 0.91 & \pm 0.95 & \pm 0.40 & \pm 1.78 & \pm 1.14 \\
\hline & Week 12 & 34.83 & 35.67 & 33.67 & 32.17 & 33.33 \\
\hline & & \pm 2.77 & \pm 1.96 & \pm 1.54 & \pm 5.00 & \pm 2.28 \\
\hline
\end{tabular}

AST; Aspartate transaminase, ALT; alanine transaminase, M; male offspring, MCG; male control group, MPG; male positive control, MDG; male drug treatment group, MTX1; treatment 1 group, MTX2; treatment 2 group. Data are expressed as mean \pm SEM and were analyzed by one-way ANOVA, followed by post-hoc LSD. Significant level set at $\mathrm{p}<0.05$. ${ }^{\mathrm{a}} \mathrm{p}<0.05$ versus positive control, ${ }^{\mathrm{b}} \mathrm{p}<0.05$ versus normal control, ${ }^{\mathrm{c}} \mathrm{p}<0.05$ versus drug treatment group

\section{IMPACTS OF E. tapos TREATMENT ON THE HISTOLOGY SECTION OF PUPS AT PND21}

The photomicrograph in Figure 2 showed the histopathological changes on the liver, RpWAT, heart, and kidney of pups at PND21. The liver histopathological examinations from MCG, MDG, MTX1, and MTX2 showed normal hepatocytes $(\mathrm{H})$ cell, sinusoids $(\mathrm{S})$ and central vein $(\mathrm{CV})$. These liver sections showed $0 \%$ of hepatocytes cells affected. However, the liver cell from MPG showed the presence of hepatocyte ballooning cells with a lesion scored of $2 \%$ but there was no lobular inflammation recorded (Panel A). Also, the histopathological examination of RpWAT from MPG showed hypertrophy of adipocytes with lesion score of $2 \%$; with bigger cell sizes but a smaller number of cell/ per filed (Panel B) compare to MCG group. The MDG, MTX1, and MTX2 showed normal adipocytes in size with a greater number of cell /per field (panel 
B). Interestingly, the histopathology of heart cell (panel C) and kidney cell (panel D) indicated no morphological changes (Figure 2).

The dysfunction of the mitochondrial caused lobular inflammation, hepatocellular ballooning, and fibrosis in the liver. The previous study has reported that increased uptake of HFD and cafeteria food is the primary reason for causing non-alcoholic fatty liver disease (NAFLD). NAFLD is associated with liver disorders such as liver cancer as well as liver cirrhosis (Pandey \& Tipathi 2014). In the current study, the histology of liver in male offspring at PDN21 and week 12 from MPG showed the presence of prominent ballooning cells compared to E. tapos treated groups (MTX1 \& 2), specifically in E. tapos shell (MTX2) extract. This ballooning cell is the early stage of changes in hepatocytes, which will lead to the present of steatosis or lipid droplet cells. This present study investigated that the $E$. tapos shell contains a high level of flavonoids that help in reducing the hepatic lipid in early stages, by lipid oxidation and improved the liver functions.
A

MC

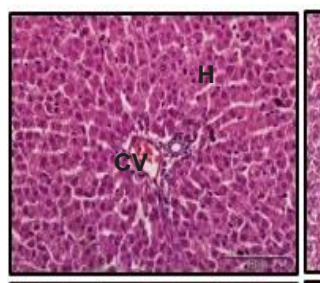

B

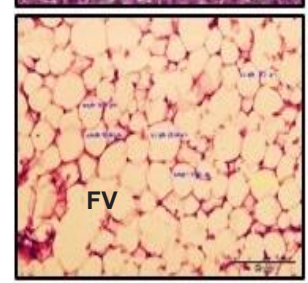

C

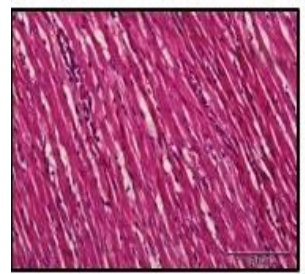

D

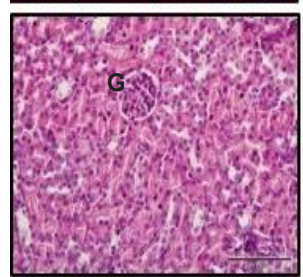

MPG
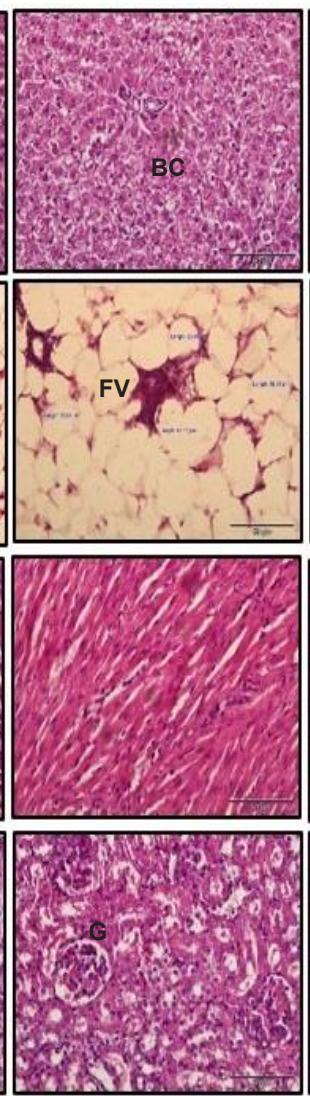

MD
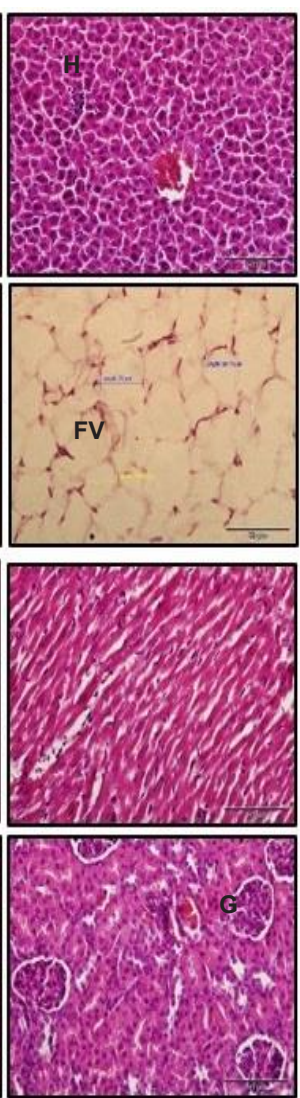

MTX
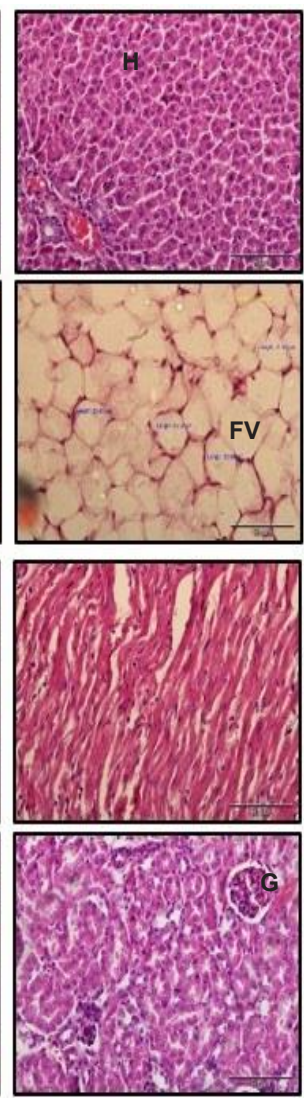

MTX
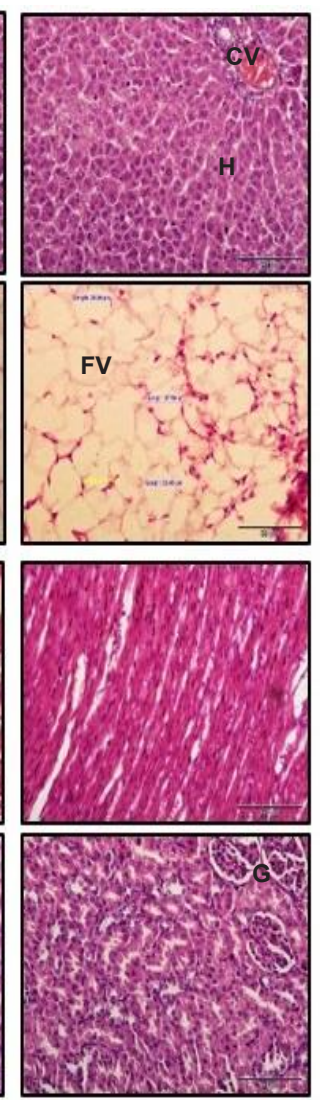

Panel (A) hepatic histology, (B) RpWAT histology, (C) heart and (D) is renal. CV, Central Vein; H, hepatocyte; S, sinusoid; BC, ballooning cell; FV, fat

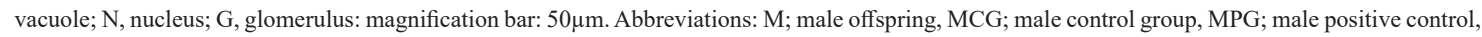
MDG; male drug treatment group, MTX1; dams treated with seed group and, MTX2, dams treated with shell group

FIGURE 2. Histology of liver, RpWAT, heart and kidney of male offspring at PND21

IMPACTS OF E. tapos TREATMENT ON THE HISTOLOGY SECTION OF PUPS AT WEEK 12

The photomicrograph in Figure 3 indicated the histopathological changes on the liver, RpWAT, heart, and kidney of pups at week 12. The liver histology from MCG, MDG, MTX1, and MTX2 showed normal hepatocytes $(\mathrm{H})$ cell, sinusoids $(\mathrm{S})$ and central vein $(\mathrm{CV})$. These liver sections showed no affected hepatocytes 
cells. However, the liver cell from MPG group indicated the presence of hepatocyte ballooning cells with a score of $2 \%$ but no lobular inflammation recorded (Panel E). The histopathological examination of RpWAT from MPG group showed hypertrophy of adipocytes with scored of
I $\%$ and bigger cell sizes but a smaller number of cell/ per filed (Panel F) compared to the MCG group. The MDG, MTX1, and MTX2 showed normal adipocytes in size with the normal number of cell/per field (panel B). The heart (panel G) and kidney cells (panel H) histology indicated no morphological changes.

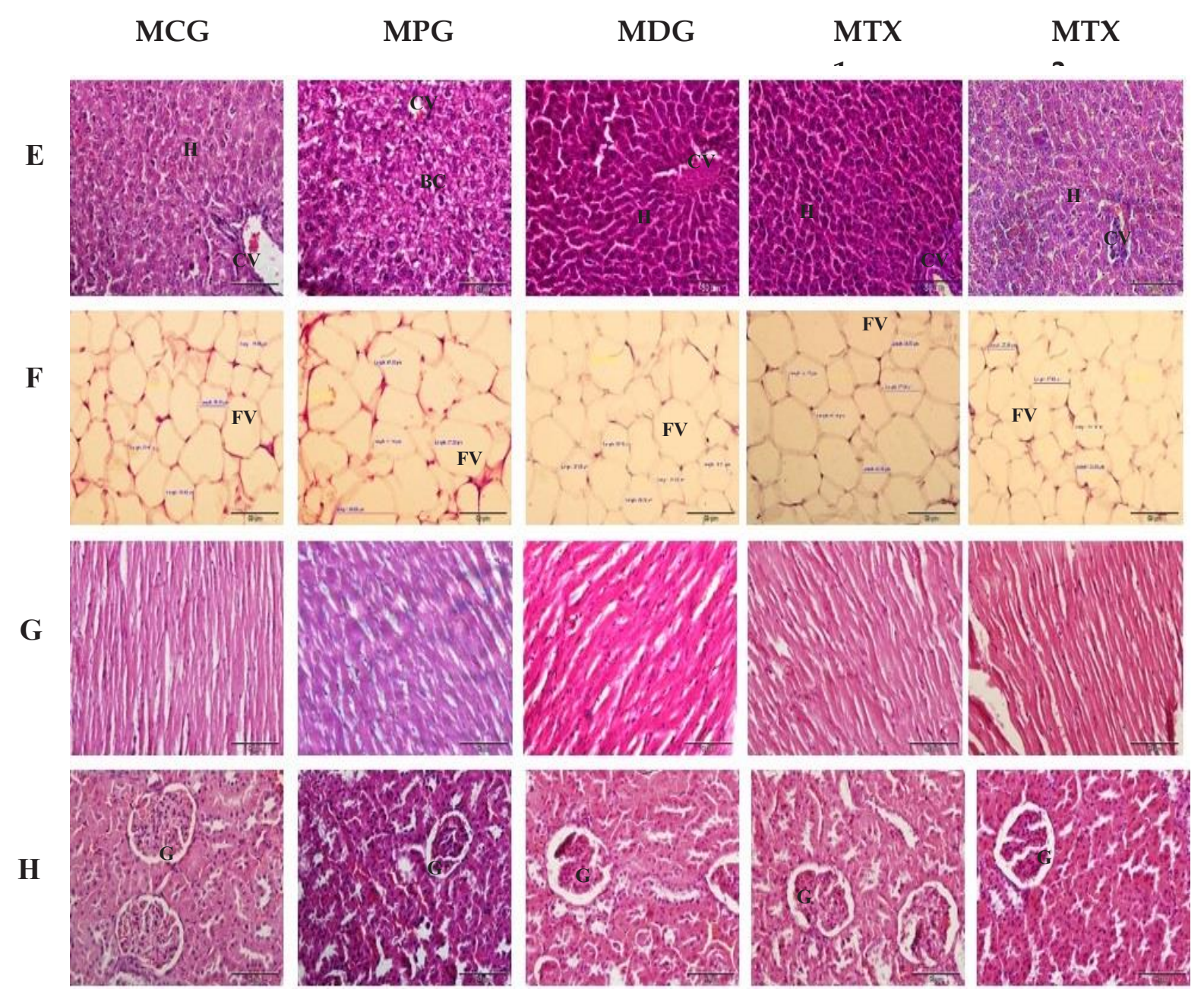

Panel E; hepatic histology, F; RpWAT histology, G; heart, H; is renal, CV; Central Vein; H; hepatocyte; S; sinusoid, BC; ballooning cell, FV; fat

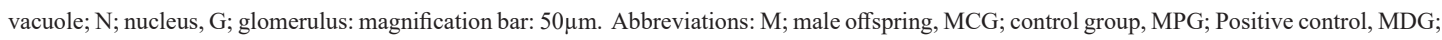
drug treatment group, MTX1; dams treated with seed group, MTX2, dams treated with shell group

FIGURE 3. Histology of liver, RpWAT, heart and kidney of male offspring at week 12

\section{LIMITATION}

Our research only covered the shell and seed of E. tapos, other parts of the plant need to be exploited for other therapeutic potential of this plant. Several factors can interfere with the transgenerational study. Methods to control and avoid those factors, especially the genetic factors are essentially needed to achieve more reliable results.

\section{CONCLUSION}

The therapeutic effect of E. tapos seed and shell extracts demonstrated significant reduction on body and organs 
weights, caloric intake, lowering adipogenesis as well as biochemical assays, on male offspring at weaning and adulthood. Changes in lifestyle and regular exercise will be the simplest and initial step to combat the effect of life-threatening obesity. The E. tapos shell extract proves to have more prominent effect as an anti-obesity supplement compared to E. tapos seed extract.

\section{ACKNOWLEDGEMENTS}

This study was approved by the Animal Care and Ethics Committee of Management and Science University, under AE-MSU-073 licensed. The authors declare no competing interest regarding the publication of this manuscript. The authors are thankful to the Department of Human Anatomy UPM and Department of Science Laboratory MSU for the facilities provided for this research. This research was funded by the Ministry of Higher Education (MOHE), Malaysia through fundamental Research Grant (FRGS/1/2016/ SKK08/UPM/02/14; 04-01-16-1813FR).

\section{REFERENCES}

Akadiri, Y. \& Kabirou, M. 2011. Maternal diabetes in pregnancy: Early and long-term outcomes on the offspring and the concept of "Metabolic Memory". Exp. Diabetes Res. 2011: Article ID. 218598.

Armitage, J.A., Tayloe, P.D. \& Poston, L. 2005. Experimental models of developmental programming: Consequences of exposure to an energy-rich diet during development. The Journal of Physiology 565(Pt 1): 3-8.

Awang, M., Furukawa, A., Kawaguchi, H., Osada, N. \& Takeda, H. 2003. Estimation of crown characters and leaf biomass from leaf litter in a Malaysian canopy species Elateriospermum tapos (Euphorbiaceae). Forest Ecology and Management 177: 379-386.

Balan, S.S., Abidin, A.Z., Perumal, K.V., Hazirah, A., Lotafi, A., Danabala, S., Manimaran, M., Shafie, N.H., Abdullah, M.A., Jasni, A.S. \& Bahari, H. 2019. Effect of Elateriospermum tapos extract as coadjuvant in ameliorating maternal obesity on female offspring at weaning. Malaysian Journal of Microscopy 15: 111-128.

Bucksch, J., Currie, D., Elgar, F., Hamrik, Z., Inchley, J., Keane, E., Kelly, C. \& Rasmussen, M. 2017. Adolescent obesity and related behaviours: Trends and inequalities in the WHO region 2002-2014, observations from the health behaviour in school-aged children (HBSC) WHO collaborative crossnational study. World Health Organization, Regional Office for Europe 130(4): 207-217. http://www.euro.who.int/_data/ assets/pdf_file/0019/339211/WHO_ObesityReport_2017_ v3.pdf.

Calton, E.K., James, A.P., Pannu, P.K. \& Soares, M.J. 2014. Certain dietary patterns are beneficial for the metabolic syndrome: Reviewing the evidence. Nutr. Res. 34: 559 568.

Cardenas-Perez, R.E., Fuentes-Mera, L., de la Garza, A.L., Torre-Villalvazo, I., Reyes Castro, L.A., RodriguezRocha, H., Garcia-Garcia, A., Corona-Castillo, J.C., Tovar, A.R., Zambrano, E., Ortiz-Lopez, R., Saville, J., Fuller, M. \& Camacho, A. 2018. Maternal overnutrition by hypercaloric diets programs hypothalamic mitochondrial fusion and metabolic dysfunction in rat male offspring. Nutrition \& Metabolism 15: 38 .

Catalano, P.M. 2003. Obesity and pregnancy-the propagation of a viscous cycle? J. Clin. Endocrinol. Metab. 88: 35053506.

Catalano, P.M., Kirwan, J.P., Haugel-de Mouzon, S. \& King, J. 2003a. Gestational diabetes and insulin resistance: Role in short- and long-term implications for mother and fetus. $J$. Nutr. 133: 1674S-1683S.

Catalano, P.M., Thomas, A., Huston-Presley, L. \& Amini, S.B. 2003b. Increased fetal adiposity: A very sensitive marker of abnormal in utero development. Am. J. Obstet. Gynecol. 189: 1698-1704.

Dyson, J.K., Anstee, Q.M. \& McPherson, S. 2014. Non-alcoholic fatty liver disease: A practical approach to diagnosis and staging. Frontline Gastroenterol. 5(3): 211-218. https://doi. org/10.1136/flgastro-2013-100403.

Ferezou-Viala, J., Roy, A.F., Serougne, C., Gripois, D., Parquet, M., Bailleux, V., Gertler, A., Delplanque, B., Djiane, J., Riottot, M. \& Taouis, M. 2007. Long-term consequences of maternal high-fat feeding on hypothalamic leptin sensitivity and diet-induced obesity in the offspring. Am. J. Physiol. Regul. Integr. Comp. Physiol. 293: R1056-1062.

Fu, Q., Olson, P., Rasmussen, D., Keith, B., Williamson, M., Zhang, K.K. \& Xie, L. 2016. A short-term transition from a high-fat diet to a normal-fat diet before pregnancy exacerbates female mouse offspring obesity. International Journal of Obesity 40(4): 564-572.

Harvey, N.C., Poole, J.R., Javaid, M.K., Dennison, E.M., Robinson, S., Inskip, H.M., Godfrey, K.M., Cooper, C., Aihie Sayer, A. \& The SWS Study Group. 2007. Parental determinants of neonatal body composition. J. Clin. Endocrinol. Metab. 92(2): 523-526.

Husin, N., Tan, N.A.H. \& Muhammad, I.I. \& Nawi, N.M. 2013. Physicochemical and biochemical characteristics of the underutilized Elateriospermum tapos. J. Teknol. 64: 57-61.

Institute of Medicine (US) Subcommittee on Military Weight Management. (2004). Weight Management: State of the Science and Opportunities for Military Programs. National Academies Press (US).

Kirk, S.L., Samuelsson, A., Argenton, M., Dhonye, H., Kalamatianos, T., Poston, L., Taylor, P.D. \& Coen, C.W. 2009. Maternal obesity induced by diet in rats permanently influences central processes regulating food intake in offspring. PLoS ONE 4(6): e5870. https://doi.org/10.1371/ journal.pone.0005870. 
Kumeshini, S., Nurshazana, A., Faizah, O., Kamsiah, J., Srijit, D. \& Zar Chi, T. 2016. Development of hypertensive animal model using ovariectomised rat fed with short-term $2 \%$ cholesterol diet. Medicine \& Health 11(2): 171-180.

Kwaifa, I.K., Bahari, H., Yong, Y.K. \& Noor, S.M. 2020. Endothelial dysfunction in obesity-induced inflammation: Molecular mechanisms and clinical implications. Biomolecules 10: 291.

Lawlor, D.A., Smith, G.D., O’Callaghan, M., Alati, R., Mamun, A.A., Williams, G.M. \& Najman, J.M. 2007. Epidemiologic evidence for the fetal overnutrition hypothesis: Findings from the mater-university study of pregnancy and its outcomes. Am. J. Epidemiol. 165: 418424.

McCurdy, C.E., Bishop, J.M., Williams, S.M., Grayson, B.E., Smith, M.S., Friedman, J.E. \& Grove, K.L. 2009. Maternal high-fat diet triggers lipotoxicity in the fetal livers of nonhuman primates. The Journal of Clinical Investigation 119(2): 323-335.

Mery, S., Guadalupe, L., Rodríguez-González, C.I., Claudia, C., Vega, P.W., Nathanielsz, P.W. \& Zambrano, E. 2014. Adult exercise effects on oxidative stress and reproductive programming in male offspring of obese rats. American Journal of Physiology-Regulatory, Integrative and Comparative Physiology 308: R219-R225.

Nassir, F., Rector, R.S., Hammoud, G.M. \& Ibdah, J.A. 2015. Pathogenesis and prevention of hepatic steatosis. Gastroenterol. \& Hepatol. 11(3): 167-175.

Noor, A.A.A., Asmah, R. \& Hawa, Z.E.J. 2015. Protective effects of Tamarillo (Cyphomandra betacea) extract against high fat diet-induced obesity in Sprague-Dawley rats. Journal of Obesity 2015: 846041.

Nor-Liyana, J., Siroshini, K.T., Nurul-Syahirah, M.B., Chang, W.L., Nurul-Husna, S., Daryl, J.A., Khairul-Kamilah, A.K. \& Hasnah, B. 2019. Phytochemical analysis of Elateriospermum tapos and its inhibitory effects on alphaamylase, alpha-glucosidase and pancreatic lipase. Journal of Tropical Forest Science 31(2): 240-248.

Oken, E. 2008. Excess gestational weight gain amplifies risks among obese mothers. Epidemiology 20(1): 82-83.

Oken, E. \& Gillman, M.W. 2003. Fetal origins of obesity. Obes. Res. 11: 496-506.

Pandey, A. \& Tripathi, S. 2014. Concept of standardization, extraction and pre phytochemical screening strategies for herbal drug. Journal of Pharmacognosy and Phytochemistry 2(50): 115-119.

Park, T.K.Y. 2011. Phytochemicals as potential agents for prevention and treatment of obesity and metabolic diseases. Anti-Obesity Drug Discovery and Development 1: $1-48$.

Perumal, K.V., Ja'afar, N.L., Balan, S.S., Zainal Abidin, A., Arapoc, D.J., Shafie, N.H. \& Bahari, H. 2019. Preventive effect of Elateriospermum tapos seed extract against obese Sprague Dawley rats. Advances in Traditional Medicine 20: 107-113.
Ramli, N. 2005. Ethanol induced kidney morphological changes in rats after acute dosing. Master. Universiti Putra Malaysia (Unpublished).

Ribaroff, G.A., Wastnedge, E., Drake, A.J., Sharpe, R.M. \& Chambers, T.J.G. 2017. Animal models of maternal high fat diet exposure and effects on metabolism in offspring: A meta-regression analysis. Obesity Reviews 18(6): 673-686.

Rodriguez-Leyva, D., Malik, A. \& Tappia, P.S. 2011. Genderrelated gene expression in response to dietary fatty acids and predisposition to atherosclerosis and cardiovascular disease. Clin. Lipidol. 6(6): 653-664. https://doi.org/10.2217/ clp.11.62.

Sanaa, R.G., Walaa, G.H., Kamal, A.A. \& Shimaa, M.R. 2014. Effects of orlistat and herbal mixture extract on brain, testes function and oxidative stress biomarkers in a rat modal of a high-fat diet. Beni-Suep University Journal of Basic and Applied Science 3: 93-105.

Wardani, H.A., Rahmadi, M., Ardianto, C., Balan, S.S., Kamaruddin, N.S. \& Khotib, J. 2019. Development of nonalcoholic fatty liver disease model by high-fat diet in rats. Journal of Basic and Clinical Physiology and Pharmacology 30: 6 .

Yong, O.Y. \& Salimon, J. 2006. Characteristics of Elateriospermum tapos seed oil as a new source of oilseed. Industrial Crops and Products 24(2): 146-151. https:// doi.org/10.1016/j.indcrop.2006.03.001.

Zhao, H.L., Sim, J.S., Shim, S.H., Ha, Y.W., Kang, S.S. \& Kim, Y.S. 2005. Antiobese and hypolipidemic effects of platycodin saponins in diet-induced obese rats: Evidences for lipase inhibition and calorie intake restriction. International Journal of Obesity 29(8): 983990.

Santhra Segaran Balan, Azrina Zainal Abidin, Kokila Vani Perumal \& Hasnah Bahari*

Department of Human Anatomy

Faculty Medicine and Health Sciences

Universiti Putra Malaysia

43400 UPM Serdang, Selangor Darul Ehsan

Malaysia

Santhra Segaran Balan \& Azrina Zainal Abidin

Department of Diagnostic and Allied Health Science

Faculty of Health and Life Sciences

Management and Science University

40100 Shah Alam, Selangor Darul Ehsan

Malaysia

Nurul Husna Shafie

Department of Nutrition and Dietetics

Faculty Medicine and Health Sciences

Universiti Putra Malaysia

43400 UPM Serdang, Selangor Darul Ehsan

Malaysia 
Maizaton Atmadini Abdullah \& Ibrahim Kalle Kwaifa Department of Pathology

Faculty Medicine and Health Sciences

Universiti Putra Malaysia

43400 UPM Serdang, Selangor Darul Ehsan

Malaysia

Azmiza Syawani Jasni

Department of Medical Microbiology and Parasitology Faculty of Medicine and Health Sciences

Universiti Putra Malaysia

43400 UPM Serdang, Selangor Darul Ehsan

Malaysia
Ibrahim Kalle Kwaifa

Department of Haematology

School of Medical Laboratory Sciences

College of Health Sciences

Usmanu Danfodiyo University (UDU)

Sokoto, North-Western 2346

Nigeria

*Corresponding author; email: haba@upm.edu.my

Received: 2 November 2020

Accepted: 13 February 2021 